\title{
An Analysis of Deixis in the Novel of 'Ketika Cinta Bertasbih 1' by Habiburrahman El-Shirazy
}

\author{
Wiwiek Sundari \\ English Department, Faculty of Humanities \\ Diponegoro University, Indonesia \\ wiwieksundari@lecturer.undip.ac.id
}

\begin{abstract}
This study was aimed to describe the deixis usage in the novel of Ketika Cinta Bertasbih 1 by Habiburrahman El-Shirazy. Theoretically, this study is expected to be useful for the researcher of language and literature, and practically, this research can contribute the importance of understanding and preserving literature through language. The researcher used a qualitative descriptive method to analyze the content. Furthermore, the data collection had been transcribed and grouped based on the characteristic, form, and function that were related to the formulation of the research objectives. Based on the data analysis, this analysis found the usage of all kinds of deixis included person (I, you, they, we, he/she), time (now, tomorrow, later), place (here), discourse (it, that), and social (sir).
\end{abstract}

Keywords: deixis, novel, Ketika Cinta Bertasbih 1

\section{INTRODUCTION}

The study of language as a means of communication has become an important aspect in linguistics. As noted by Robert (2002) cited in (Arbain, 2016) the communicative functions of language is reference and predication, that is, representing thing that happen in the world (or a possible fictional world) and the participants involved in those situations. It means that when people do communication, they share the meaning in spoken utterance or written text which can be known from its context (Irawan \& Andriani, 2018). The words which are interpreted its meaning based on the context is called deictic or deixis.

As one of the studies pragmatics, deixis has a referent that move around depending on the situation its use. Deixis makes meaning language becomes more organized and effective so it doesn't cause confusion and does not cause a different perception on the recipient of the language Horn \& Gregory (2006) in (Siahaan, 2017). Further, they stated that the use of language in communication makes it easy for the user. One of these conveniences is the existence of a reference system and referential. The reference system can provide convenience but also cause confusion, and misunderstanding of meaning between language users in understanding the meaning and reference. In such, one who is able to understand the referent of an utterance he must be also able to identify the context and speech. Therefore, this understanding of references closely related to understanding the deixis usage. This is in line with Purwo (1985) in (Setiakawanti \& Susanti, 2019) who suggests that a word is deictic if the referents move or change, depending on the person being speaker and depending on the time and where the words were spoken. Deixis are divided into five forms, namely deixis persona, place/space deixis, deixis time, discourse deixis, and social deixis (Yuliani et al., 2013). The five deixis are mutually influenced and complement each other. Thus, dseixis is useful as an explanation the meaning of the speech so that the meaning contained in the speech is acceptable well by readers. This matter is the goal in language that needs to improve on each language user. The use of deixis can found in various sources. One of sources containing words and phrases deixis is a novel.

In addition, deixis concerns the ways in which a language encodes or grammaticalizes features of the context of utterance or speech event, and thus also concerns ways in the interpretation of utterances on the analysis of that context on utterance (Nursafira et al., 2019). To sum up,(Desmawati, 2018) states that deictic terms are used to refer to ourselves to other and 
to object in our environment. Deixis used to locate actions in a time frame relative to the present. Deictic term shows social relationship the social location of individual in relation to other parts. One of the literary of social relationship that absorbs the reality of life and elevates the values contained in the society is novel.

A novel is a literary work that explores the human life, both individual and collective existence in the face of problems that occur, for example, with fellow human beings, the environment, and yourself (Susanti \& Susanti, 2018). It is one form of a literary work, novel is a fictional story in the form of writing or words and has intrinsic and extrinsic elements. A novel usually tells about human life in interacting with the environment and each other. In a novel, the author tries his best to direct the reader to pictures of the reality of life through the stories contained in the novel (Nurgiyantoro, 1994). Therefore, this study is concerned to analyze the deixis usage in the novel of Ketika Cinta Bertasbih 1. The novel has a living area which is too wide and depicts the life of people's relationship. The stories portrayed the reality that is imagined by the thought of the author. The author is not a public servant, but he managed to turn the imaginary and sensitivity skills through writing the novel. In short, this novel tells the story of three teenagers who are studying at a college in Cairo, namely Al-Azhar University, who in their journey to study they have many obstacles that they must face. Conflicts that hit them was mainly a matter of obstacles, the three of them were: Anna Altafunnisa, Khairul Azzam, and Furqan, Andi Hasan, and other supporting roles.

The language use in the novel of Ketika Cinta Bertasbih 1 generated social meanings, and the novel showed the ability of users to associate language sentences with appropriate contexts for the novel there is a series of words, including the selection and use of words that are deixis. A word is said to be deixis if reference moving or changing, depending on the time and place of the word spoken, for example, word I, here, and now. Deixis signals a referent and it relates that referent to a common ground shared by the speaker and the addressee. It is the ability to situate the speaker and hearer in relation to one another and to the world around them. Levinson
(1983) cited in (Ramasari, 2020) says that deixis belongs within the domain of pragmatics, because it directly concerns the relationship between the structure of languages and contexts in which they are used. Lyon (1983) in (Putri \& Yana, 2020) argues that the notion of deixis (which is merely the Greek word for 'pointing' or 'indicating' it becomes a technical term of grammatical theory) is introduced to handle the 'orientational' features of language which are relative to the time and place of utterance.

Furthermore, deixis implicates not only the characteristic functions of the demonstrative pronouns but also tense and person, and a number of other syntactically relevant features of the context of utterance. As quoted from Levinson's book "Pragmatics" in (Muqit, 2019) there are five kinds of deixis, they are: person deixis, time deixis, place deixis, discourse deixis, and social deixis. Thus, in this study, the researcher will be going to use those kinds of deixis in analyzing the novel of Ketika Cinta Bertasbih 1.

\section{METHODOLOGY}

This research applied qualitative descriptive method. Data used in this research are words and sentences that contain deixis in the novel of Ketika Cinta Bertasbih 1. The novel was written by Habiburrahman El Shirazy and was released in 2007. Further, this study was conducted with a number of procedures as follows: 1) collecting the data from the utterances which are found in that novel, 2) identifying and classifying the data usage of deixis of person, time, place, discourse, and social, 3) making the description the usage of deixis by the characters and the referent of the deixis, and 4) making the conclusion usage of deixis data.

\section{FINDINGS AND DISCUSSION}

Based on data analysis, Ketika Cinta Bertasbih 1 novel by Habiburrahman El - Shirazy included a number of deixis, namely person deixis, place deixis, time deixis, discourse deixis, and social deixis. The following was the analysis of each deixis.

\section{Person Deixis}

Person deixis is one form pronomina deixis (Herman \& Pardede, 2020). In the novel of Ketika 
Cinta Bertasbih 1 was found the usage of person deixis, both the first and second person deixis or third person. Furthermore, the following was the three types of person deixis analysis.

\section{First Person Deixis Single}

1) Person Deixis I (Aku)

The following were the example of person deixis $(A k u)$ that were found in the novel.

a) I $(A k u)$ am amazed to any students' discipline like Mr. Engineer (p. 5).

b) But, I $(A k u)$ have promised to give special present (p. 15).

c) Relaxed. I (Aku) have nothing to do tonight (p. 24).

I $(A k u)$ was at the data (a) refers to Eliana. In this conversation, Azam did not reply with any words, he just smiled to Eliana.

Meanwhile, in data (b) experienced a transition deixis $I$ was referring to Eliana. This could be seen in the quote conversation between Ashraf and Fahri on page 15, namely:

She said, "I have promised to give special present". Then, Azam replied, "It's not important..."

Usage person I $(A k u)$ in the data (3) refers to Eliana who was talking with Azam. It could be seen in the following conversation excerpt.

"Relaxed. I $(A k u)$ have nothing to do tonight", said Azam.

\section{2) Person Deixis I (Saya)}

The following were the example of person deixis (Saya) that were found in the novel.

a) Yeah, I (Saya) know Sir. I've ever gone there. (p. 46)

b) Should I (Saya) marry her? (p. 48)

Person I (Saya) on the data (a and b) was referring to Azam. In this conversation, Azam was talking with Pak Ali. Pak Ali was discussing about a girl who was the first actress in the novel.

Based on the data analysis it can be concluded that there are two forms deixis first person in the novel of Ketika Cinta Bertasbih 1, namely (1) person I (aku) and (2) person I (saya). Each of these first persona has a different referral using. Person I (aku) in the novel of Ketika Cinta Bertasbih 1 based analysis used in informal situations, for example in speech acts between two participants who had the equal age, while person I (saya) was used in formal situations to speak to the older one.

\section{First Person Deixis Plural}

1) Person Deixis We (Kita)

In the novel of Ketika Cinta Bertasbih 1 was found a number of first person plural deixis we (kita), as seen in the data excerpt below:

a) Let us (Kita) go to Hadiqah Dauliyah... (p. 84) Tiara and Cut Mala

b) We (Kita) should have a discussion while enjoying the sun rise (p.85) Azam to Hafiz

Data (a) was a conversation between Tiara and Cut Mala, while (b) was between Azam's blandishment to Hafiz. Plural deixis person we (kita) is exclusive plural, because they are talking partners involved.

\section{2) Person Deixis We (Kami)}

The usage of the word we (kami) in this novel were seen in the data below:

a) We (Kami) are so sorry about the havoc. (p.144)

b) We (Kami) are six persons. (188)

Deixis we (kami) person in the data is the first inclusive person plural. It meant, person we (kami) in the novel of Ketika Cinta Bertasbih 1 partner does not involve the talking.

\section{Second Person Deixis Single}

1) Person deixis you (Kau)

In the novel was found deixis second person. It was seen, for example, in the data below.

a) You (kau) said that you will concern with your study. Do you (kau) forget it? (p.85)

b) This is a desease, you ( $k a u$ ) have to be aware Fez! (p.85)

c) Have you (kau) prayed for Tahajjud? (p.194)

Person deixis you (kau) above were included to second person deixis (Solvegia, 2013). The 
form chosen for the speaker and talking partners are familiar or of differences in social status. In the novel, deixis you ( $k a u)$ was used by people who have a higher social status to greet the other person a lower social status.

\section{2) Person deixis you (kamu)}

Usage person deixis you ( $k a m u)$ in this novel were shown below:

a) Have you (kamu) ever met Anna? (p.70)

b) Please not to use the earphone. You (kamu) will not hear Adzan. (p.154)

Persona diexis you (kamu) above were used in between two parties who are already familiar relationship, like Fadil, Azzam, and Pak Ali.

\section{Second Person Deixis Plural}

1) Persona Deixis You (Kalian)

a) The night will be coming. You (kalian) have to be here. (p.145)

b) Where did you (kalian) get them? (p.286)

Person deixis on the data (a) refers to Azam and Nanang, and the utterance was delivered by a driver when he carried them. While, the data (b) was happening to Kolonel Fuad and the citizen.

\section{Third Person Deixis Single}

1) Person Deixis He/She (Ia)

Person deixis he/she (ia) also used in the novel of Ketika Cinta Bertasbih 1. Deixis use it shown in the example below.

a) I believe that Anna has a decision. She (ia) is just confused. (p.291)

b) I hope that you will not be shocked with my explanation. The girl is Golda Olmetz. She (ia) works in a prostitution... (p.299)

On the data (a) third persona he (ia) was stated by Furqon to refers to Anna. While, the data (b) was also stated by Furqon to refer to a girl, named Golda.

\section{2) Person Deixis He/She (Dia)}

In the novel, it was found the form of third person deixis (dia). The following is an example of the intended use deixis form:

a) He is my father (p.158)

b) Yeah, he (dia) had ever won the competition of Musabaqah Tilawatil Quran in Aceh (p.266)
On the data (a) the form of he (dia) referred to Furqon's father. The statement was a respond to a girl on the phone. Furthermore, the form of he (dia) was on the data (27) referred to Azam, and it was uttered by Zahraza.

\section{3) Persona Deixis He/She (Beliau)}

In the novel, it was also found the form of third persona deixis he/she (beliau). The following is an example of using the form of it.

a) And my mother will be happy if Mbak Elia goes to my house by wearing Muslimah's clothes. She (beliau) may say there is a beautiful angel coming to me. (p.322)

On data (29) shows that he (beliau) refers to Azam's mother. According Purwo (1984: 24) third persona deixis may assert persons or things (including animals) and the first and second deixis persona just stating people. Essentially deixis is a way to interpret utterances based on the context of speech analysis.

\section{Third Person Deixis Plural}

1) Person deixis they (mereka)

In the novel of Ketika Cinta Bertasbih 1 was found third person deixis them (mereka). The following is an example of 'mereka'.

a) They (mereka) enjoy their life (p.185).

b) They (mereka) are coming (p.262)

Person they (mereka) in the data (a) refers to Azam's friends. In this case, Azam just speaks to himself, because he looked his friends were sleeping nice. While, the data (b) was referring to Azam and his little sister. It was uttered by their mother.

Based on analysis of deixis of Ketika Cinta Bertasbih 1 novel, it is known that plural persona they (mereka) are under a changing reference. This is due to the change of context.

\section{Place Deixis}

The concept of the distance is relevant to spatial deixis, it refers to the relative location of people and things are being indicated. In the 
novel of Ketika Cinta Bertasbih 1 was found deixis which refers to the place, as shown below:

1) ... ordering any food to be delivered here (ke sini). (p.173)

2) Coming here (ke sini)? To our home? (p.262)

The form of here (ke sini) in the data (a) refers to a Mbak Zulfa's house, whereas the form of here (di sini) in the data (b) refers to a specific place (Azam's house). Thus, an understanding of the two forms of the same requires the involvement of the context the word is used.

\section{Time Deixis}

Deixis shows the unit of time in the speech. It distinguishes between the moment of the utterance (coding time) and the moment of the reception (receiving time). The following English sentences difference would seem obvious:

1) The receipt will be given later (nanti). (p.14)

2) Okay, now (sekarang) we go to buy anything you need... (p.15)

3) How if we discuss something after Subuh tomorrow (besok)? (p.26)

Even if the use of deixis temporal above in principle have been standard, but the 'time' we can use/say with a more explicit description, using o'clock, date, day, year, and so, for example at 9.00 a.m, Monday, etc.

\section{Discourse Deixis}

Deixis indicates the reference marker in a section of discourse, and discourse deixis is also known as 'text deixis. The forms are often used to express deixis discourse, of which, is deixis which includes pronouns, both persona and demonstrative, deixis place, and much more. Furthermore, the deixis discourse contained in the novel of Ketika Cinta Bertasbih 1 were showed at the data below.

1) You said that you will concern with your study. Do you forget it? (p.85)

2) - I have a good news.

- What is that? (p.118)
The evident of $\underline{i t}$ above refers to your study. Whereas, the evident of 'that' refers to the good news.

Deixis discourse is relating to certain parts of the discourse that has been granted or being developed (Levinson, 1983). In relation to pragmatic competence, deixis discourse can be used to generate and interpret the discourse as a whole. In other words, by understanding deixis this discourse, pragmatic competence in Indonesian language properly and correctly increases.

\section{Social Deixis}

Deixis indicates social relationships and social levels. It involves mark of social relationships with direct or oblique reference to the social status or role of participants in the speech event. The use of deixis social most visible is the use of what are called aspects of language, such as politeness (kesopanan) or 'speaking ethical' (etika berbahasa) (Nababan, 1987). Furthermore, Novel of Ketika Cinta Bertasbih 1 provided specific views with the use of deixis social, and it can be seen in the data below:

1) Sir, we don't need to talk about the Malaysian's students, just discuss about the first topic. The sun has shone, and we didn't get breakfast yet. (p.41)

2) You have to believe in yourself Mas, that everything will be okay. Remember, Allah will follow someone's prejudice. (p.311)

Deixis social category can be said to mark an opponent said social status (Hasanah, 2016). In a social context, in the novel of Ketika Cinta Bertasbih 1, individuals specifically marked social differences in between speakers and opponents said the higher, older, or more powerful. Moreover, in deixis social formation contained social differences on the role of participants, particularly the aspect of social relationship between the speaker and the slistener or the speaker with reference to the topic.

\section{CONCLUSION}

In this study, the literary works novel of Ketika Cinta Bertasbih 1 reflected the deixis usage built by the characters. It was found that the dominant species in the novel deixis was deixis pronouns 
person. This was related to the existence of characters as the driving narrative, forming a story line. Moreover, the characters developed dispositive given form and content by the author. The main character as a recurring character in the telling of the story often use pronomina I (aku). Furthermore, this novel was also found the use of deixis place, deixis time, deixis discourse, and deixis social. Each of these deixis related closely by grammatical traits context speech or speech related events interorestation utterances are highly dependent on the context of the speech.

\section{REFERENCES}

Arbain, A. (2016). an Analysis on the Plot of Jane Austens Novel "Pride and Prejudice." LINGUA: Journal of Language, Literature and Teaching, 13(1),

127. https://doi.org/10.30957/lingua.v13i1.20

Desmawati, E. (2018). Analysis of Feminism in the Novel of Little Women By Louisa May Alcott. Journal of Language and Literature, 6(2), 91-96.

https://doi.org/10.35760/j11.2018.v6i2.2487

Hasanah. (2016). A Pragmatic Study on Deixis in the Song Lyric of Harris J'S "Salam" Album. UIN Malang.

Herman, H., \& Pardede, H. (2020). Deixis Analysis in the Business Article of the Jakarta Post. Wanastra: Jurnal Bahasa Dan Sastra, 12(2), 137-141. https://doi.org/10.31294/w.v12i2.8464

Irawan, R., \& Andriani, D. (2018). An Analysis of Educational Values of Novel " Maze Runner " by James Dashner. Journal of English Language Education and Literature, 3(1), 38-50.

Levinson, S. C. (1983). Pragmatics. Cambridge University Press.

Muqit, A. (2019). the Analysis of the SocioPolitical Fiction Novels Under Binary Opposition (Case Study of Indonesian Novel Entitled "Orang-Orang Proyek" By Ahmad Tohari). Informasi, 49(1), 65-76. https://doi.org/10.21831/informasi.v49i1.237 28
Nababan, P. (1987). Ilmu Pragmatik (Teori dan Penerapannya). Proyek P2LPTK, Dirjen Dikti. Depdiknas.

Nurgiyantoro, B. (1994). Teori Pengkajian Fiksi. Gajah Mada University Press.

Nursafira, M. S., Putri, W. C., Yunira, S., Gari, N., \& Hamuddin, B. (2019). Psychological Analysis of Fatih's Character-Building in Egosentris: A Novel by Syahid Muhammad. Elsya: Journal of English Language Studies, 1(1), $1-10$. https://doi.org/10.31849/elsya.v1i1.2461

Putri, J. A., \& Yana, Y. (2020). Deixis on Tribunnews.Com "the Story of Ade Jigo Was Rolled Up By the Tsunami 2018." PROJECT (Professional Journal of English Education), 3(6), 703. https://doi.org/10.22460/project.v3i6.p703710

Ramasari, M. (2020). an Analysis of Deixis Existed on Articles At Jakarta Post. Journal of Language and Literature, 8(2), 146-169. https://doi.org/10.35760/jl1.2020.v8i2.3369

Setiakawanti, R. N., \& Susanti, E. (2019). Analysis Pragmatic Study on Deixis in the Articles Jakarta Sport. PROJECT (Professional Journal of English Education), 1(6), 757. https://doi.org/10.22460/project.v1i6.p757762

Siahaan, S. (2017). Plot Concept Analysis of Montgomery's Novel. Anglo Saxon: Jurnal Ilmiah Program Studi Pendidikan Bahasa Inggris, 8(2), 194-206.

Solvegia. (2013). The Usage of Deixis in Advertising Slogans Related to Fragnance. Siauliai University.

Susanti, I., \& Susanti, I. (2018). Volume 9, No. 2, August 2018. 9(2), 68-82.

Yuliani, Salombe, M. K., \& Waris, A. (2013). An Analysis the Main Characters and the Plot in the Novel of Bacharuddin Jusuf Habibie's Habibie aZahroni. (2016). An Analysis of Characters in "I Love You Mom" Short Story Book By Arleen Amidjaja. Literary Criticism Journal.nd Ainun. Journal of English Language Teaching Society, 1(1), 1-14. 